\title{
Human capital and economic growth in Nigeria
}

\author{
Sunday Anderu Keji $1^{1,2^{*}}$
}

\begin{abstract}
The study empirically examines the nexus between human capital and economic growth in Nigeria between 1981 and 2017. This is predated by poor policy impact across the key sectors of the economy, such as education and health that would have transformed productivity to economic in Nigeria. In order to address this ugly happening, the study therefore employed vector autoregressive and Johansen techniques. The results disclosed that the estimated coefficients of human capital have long-run significant impact on economic growth in Nigeria. Also, the diagnostic tests were used to check the validity of the techniques adopted in the study. Interestingly, results from normality test, VEC residual serial correlation LM tests and VEC residual heteroskedasticity tests confirm the justification and validity of the estimated results obtained in this research. Drawing way forward, this study therefore recommends the need to sustain economic in Nigeria through increase budgetary allocation to education and health sector to boost human capital skills needed to drive knowledge-based economy. Also, government should establish special agencies with the responsibility of improving the skills and capabilities of human capital across all educational levels of the federation so as to sustain growth in the long run.
\end{abstract}

Keywords: Human capital, Economic growth, Policy

JEL Classification: 115, 122, O4

\section{Introduction}

Over the years, the cause to improve and sustain human capital gains across the world had remained contentious in terms of achieving macroeconomic objectives of any given economy. Again, in the time past, Africa witnessed poor health outcomes that are predated by low life expectancy and huge mortality, and this has drawn the needed attention in the forefront towards improving productivity through improved health outcomes [13]. Human capital engenders productivity which can be aided by healthy conditions, knowledge, skills, work experience and motivation [6, 12]. Similarly, Harbinson [9] argued that the cautious and incessant process of acquiring requisite

\footnotetext{
*Correspondence: sunday.keji@fuoye.edu.ng

${ }^{1}$ Department of Economics, Federal University Oye-Ekiti, Oye, Ekiti State, Nigeria

Full list of author information is available at the end of the article
}

knowledge, skills and experiences are applied to produce economic value required for sustainable growth.

Notwithstanding, Nigeria is rather characterised by under-investment in human capital through the two major tracks: education and health. To this end, persistence and continuous investment or spending in human capital spur long-run productivity hence improved economic growth performance [16, 17]. The country had in the time past tried to come up with different programmes, for instance, the Nigerian government designed National Health Insurance Scheme (NHIS) to improve workers' productivity by reducing out of pocket hospital bills settlement. Human capital is measured by education, health, training among other factors that can promotion productivity [21]. The workings of human capital development such as health and education are closely connected modules that work together to make the individual productive. 
Despite the fact that Nigeria is immensely endowed both in terms of human and physical resources which are almost unquantifiable, hence, the country is faced with major problems like shortage of skilled labour, huge unemployment, poverty and poor healthcare system, etc. [3]. It is a great risk for any country to rely on foreign aid to fund education as this would exacerbate vulnerability of small open economy to external shocks $[19,22]$.

Obi and Obi [15] investigated the impact of education expenditure on economic growth between 1981 and 2012 through Johansen cointegration technique. The findings revealed that there are no long-run relations between government spending and economic growth. Meanwhile, Borojo and Jiang [5] examined the impact of human on economic growth between 1980 and 2013 in Ethiopia via cointegration technique, which disclosed that long-run relationship exists between human capital indicators and economic growth indicator. Amassoma and Nwosa [4] argued that there are no nexus and causal links between investment in human capital and economic growth in Nigeria. The study examines the relationship between investment in human capital and economic growth in Nigeria through vector error correction (VEC) and pairwise Granger causality techniques.

Findings from the previous scholars, such as Amassoma and Nwosa [4], Adeyemi and Ogunsola [2], Ekesiobi et al. [7] among others, showed that there is no consensus on the link between human and economic growth. Similarly, the ugly scenario ranging from poor healthcare system to poor educational set-up which have brought no significant growth to Nigeria's economy in the time past prompted this research. In lieu of this, it is pertinent to investigate the link between human capital and economic growth in Nigeria. To this end, various questions enthused thus what is the trend of human capital on economic growth in Nigeria? What is the nexus between human capital and economic growth in Nigeria?

In view of this, the discoveries from this study would provide cutting edge clarifications thus; the results from the study would aid relevant agencies and policy makers in addressing the pressing economic issues in Nigeria. In the same way, this study shall cover the period between 1980 and 2017, a period of thirty-eight years. This era is primarily relevant to address questions raised from the study and the history of Nigeria because it covers a period of her deficit financing of long-term schemes in human capital coupled with economic recession.

This write-up is divided into five sections; section one encompasses the introduction. Section two explains the conceptual, theoretical and empirical literature review, section three addresses the methodology. Section four incorporates the data representation and analysis, whereas section five therefore contains the conclusion and policy recommendations.

\section{Literature review}

The concept of human capital could be related to other forms of capital. Investments in human capital yield income and other benefits over a long-time Oluwatobi and Olurinola [18]. Hence, the concept of human capital is said to be the skills and efforts of human resources in any given economy that is geared towards attaining economic growth. Notably, human capital can be improved over time, through either informal or formal skill acquisition, as well as other social investment that enhances productive capacities of labour [1]. Hence, drawings from the above, human capital could therefore be defined as the abilities and skills attained by the working age which are possessed in the cause of production to achieve economic growth, while economic growth, according to Jhingan [10], is spontaneous rise in the amount of goods and services produced in a given small open economy, specifically for calendar year. Economic growth is one of the most important indicators of a healthy economy, which has been regarded as sine qua-non for achieving macro-economic objectives. It is interesting to note that relevant economic model such as endogenous growth model, accounts for the vital role of human capital in the cause of achieving economic growth. Specifically, Mankiw et al. [14] opined for further improvement [20] which is termed "the augmented Solow model". This emphasised on non-homogeneity in the production process which is due different level of human capital investment over time.

Meanwhile, over the years several studies have emerged in an attempt to provide quantitative evidence to the effects of human capital on economic growth in Nigeria. For instance, Adeyemi and Ogunsola [2] argued that human capital investment has positive and long-run significant impact on the Nigerian economy. The study applied ARDL and cointegration techniques through secondary data, and they hence suggested that government should focus more it spending on human capital in education sector so as to sustain economic growth in Nigeria. In a related study carried out by Adelakun [3] on human capital development economic progress in Nigeria, the author disclosed that human capital development has a direct and significant effects on the Nigerian economic growth, using ordinary least squares (OLS) technique. On the contrary, Obi and Obi [15] examined the effects of government on education in relation to economic growth between 1982 and 2012, through Johansen's cointegration analysis. The study therefore revealed that there is no long relationship between education spending and 
economic growth in Nigeria. Based on this discovery, the study therefore suggests that education policies should be reformed through accountability and transparency in contractual transactions.

Ekesiobi et al. [7] inspected the effect of public spending on education and manufacturing output in Nigeria. The study employed ordinary least square (OLS) technique to analyse the relationship between public spending on education and manufacturing output growth. The findings revealed that public education spending has a positive but insignificant effect on manufacturing output growth in Nigeria. They recommended among other things that government should target education spending in education on vocational studies that could favour manufacturing output growth. Similarly, Amassoma and Nwosa [4] examine the relationship between human capital investment and economic growth in Nigeria between 1970 and 2009 through vector error correction (VEC) and pairwise Granger causality techniques. The findings disclosed that there are no nexus and causal links between investment in human capital and economic growth. The study recommends the need to improve budgetary allocation, especially to education and health sector. Also, the study recognised the need to address labour mismatch in some government in order to accelerate and sustain economic growth.

In so far, it appears that there are disconnections and no consensus from the previous works on the nexus between human capital and economic growth in Nigeria subsist. This might be connected to different factors; for example, measurement errors by some previous are mostly associated with the variables used in evaluating human capital. And this has risen concerns on the actual indicators of human capital that can spur economic progress. Similarly, in a related study, another gap observed from the methodological perspectives that have brought disagreements and divers empirical outcomes. Notably, Kairo et al. [11] and Adeyemi and Ogunsola [2] applied similar econometric methods-autoregressive distributed lags (ARDL) to assess the link between human capital investment and economic progress in Nigeria; the authors came up with diverse inferences. For instance, Kairo et al. [11] submitted that government investment in human capital has no link with economic progress. Meanwhile, Adeyemi and Ogunsola established that there is link between human capital development and economic growth. In view of these diverse views, the researcher wishes to test the strength of the improved human capital variables against the economic growth indicator in order to establish whether human capital determinants spur economic progress in Nigeria or not. Interestingly, this study intends to apply a robust econometric technique like vector error correction mechanism (VECM) in line with statistical rule of thumbs to address the disconnections from the previous works. Again, using VECM would help the researcher to answer some questions that emerge from the problem statement above. In an attempt to address this disconnect, it is pertinent to investigate the link between human capital and economic growth in Nigeria between 1981 and 2017. This is an attempt to fill the necessary vacuum yet to be filled by the earlier scholars.

\section{Methodology}

According to Mankiw et al. [14], labour possessed nonhomogeneity in the production process as a result of different level of human capital investment over time. This is in line with the work of Oluwatobi and Olurinola [18] model, which this research intends to adopt with slight modification. This study, therefore, endogenously expressed human capital model thus:

$$
Y=A K^{\alpha}(h L)^{\beta}
$$

where $Y=$ output; $K=$ physical stock of capital; $h=$ rate of human capital; $L=$ labour in terms of labour force; $A=$ rate of factor productivity; $\alpha=$ elasticity of capital input in relationship to output $Y$, while $\beta=$ elasticity of labour input in relationship to output $Y$. To this end, the model is explicitly expressed thus;

$$
Y=F(K, h, L)
$$

where $Y=$ output; and $K=$ physical stock of capital; $h=$ rate of human capital; $L=$ labour as $F=$ function of output growth. That is, the output growth is determined by stock of capital $(K)$, proportion of human capital $(h)$ and labour efforts $(L)$.

\section{Model specification}

Following the endogenous growth model, the following model is stated so as to investigate the nexus between human capital and economic growth in Nigeria. For more detailed empirical revelation, it is pertinent to econometrically express the model for the purpose of smooth data analysis of the study.

The functional relationship of the model is expressed as:

$$
\mathrm{GDP}=f(\mathrm{GCF}, \mathrm{TLF}, \mathrm{SER}, \mathrm{LPR} \text {, and GXE) }
$$

where $\mathrm{GDP}=$ gross domestic product growth rate, $\mathrm{GCF}=$ gross capital formation, $\mathrm{LPR}=$ labour participation rate, $\mathrm{SER}=$ student enrolment, $\mathrm{TLF}=$ total labour force, $\mathrm{GXE}=$ government expenditure.

For the purpose of empirical computation the structural form of the model is expressed as: 


$$
\begin{aligned}
R G D P t= & \alpha_{0}+\alpha_{1} S E R+\alpha_{2} T L F+\alpha_{3} L P R \\
& +\alpha_{4} G X E+\alpha_{5} G C F+\varepsilon
\end{aligned}
$$

That is, GCF as gross capital formation, LPR as labour participation rate SER as student enrolment, TLF as total labour force, GXE as government expenditure are to be inputted to E-view software package for empirical estimation.

\section{Estimating technique}

Augmented Dickey-Fuller (ADF) test is employed to test for the stationarity of the time series data. The ADF test can be obtained by applying the estimate in the following form of regression thus:

$$
\Delta Y=\beta_{1}+\beta_{2} t+\delta Y_{t-1}+\sum_{i=1}^{m} \alpha \Delta Y_{t-1}+\varepsilon_{t}
$$

where $\Delta Y_{t-1}=\left(Y_{t-1}-Y_{t-2}\right) \Delta Y_{t-2}=\left(Y_{t-2}-Y_{t-3}\right)$, etc.

From above Eq. (5), the first step is to estimate whether the variables in the model have unit root or not, after which appropriate technique would be adopted based on the order integration of the augmented Dickey-Fuller unit root test, meaning that unit order of ADF result, i.e. I (0)'s predict adoption of ordinary least square (OLS), while mix order of unit root test, i.e. I (0)'s and I (1)'s suggest ARDL bound cointegration techniques as the case may be, whereas I (1)'s unit order of ADF test result predicts vector error correction mechanism and Johansson's cointegration test as the case may be.

\section{Data and empirical analysis}

The section begins with descriptive statistics followed by the trend analysis of the series employed. The unit root test is carried out through augmented Dickey-Fuller test in order to ascertain the time series characteristics of each variables, followed by vector autoregressive scheme and Johansson cointegration analysis to test for both short-run and the long-run relationships of the variables in the model. At the end of this section, some post estimations diagnostics test was carried out to test for validity of the estimated results.

\section{Summary of descriptive statistics}

Descriptive statistics shows the characteristics of the data employed in the study, which eventually directs us to define the appropriate methodology for estimation.

It can be seen from Table 1 RGDP denotes real gross domestic product, SER signifies student enrolment, TLF means total labour force, LPR explains labour participation rate, and GCF indicates gross capital formation and GXE government expenditure on education. The estimated mean value is used to examine the pattern of dispersal, and the figure values for RGDP, SER, TLF, LPR, GCF and GXE are 3.23476, 23.48421, 31,168,222, 24.58947, 57.2961 and 38.10093 discretely. The standard deviation disclosed that TLF and GCF at 20,351,732 and 18.79616 demonstrate high variability, while values for SER, LPR, RGDP and GXE disclose low variability. Summarily, all the variables under this study are widely dispersed around their means, indicating that they are grossly affected by their extreme value. GCF and GXE, GCF are positively skewed, while RGDP, SER, TLF, LPR are negatively skewed. Kurtosis can either flat or peak of the normal curve. It estimates the "tailedness" of the probability distribution of a real-valued random variable. It is normal distribution and mesokurtic if kurtosis equals 3 , platykurtic if kurtosis is less than 3 and leptokurtic if kurtosis is greater than 3 . In the study, some series such as SER, TLF, LPR were platykurtic in their distribution,

Table 1 Descriptive statistics

\begin{tabular}{lllllll}
\hline & RGDP & SER & TLF & LPR & GCF & GXE \\
\hline Mean & 3.23476 & 23.48421 & $31,168,222$ & 24.58947 & 57.2961 & 38.10093 \\
Median & 4.217446 & 26.1000 & $36,520,734$ & 29.7000 & 9.980174 & 37.79074 \\
Maximum & 15.32916 & 56.2000 & $59,035,065$ & 38.7000 & 257.7200 & 89.38105 \\
Minimum & -13.12788 & 1.00000 & 100.0000 & 0.10000 & 0.010000 & 14.90391 \\
Std. dev & 5.53699 & 16.93652 & $20,351,732$ & 14.77481 & 81.94652 & 18.79616 \\
Skewness & -0.903043 & -0.097389 & -0.608474 & -0.748476 & 1.29698 & 0.92482 \\
Kurtosis & 4.583375 & 1.853509 & 1.943302 & 1.917229 & 3.19884 & 3.705407 \\
Jarque-Bera & 9.134286 & 2.141268 & 4.112824 & 5.404327 & 10.71626 & 6.204711 \\
Probability & 0.010388 & 0.342791 & 0.127912 & 0.06706 & 0.00471 & 0.044943 \\
Sum & 122.9209 & 892.400 & $1.18 \mathrm{E}+09$ & 934.400 & 2177.252 & 1447.835 \\
Sum Sq. dev & 1134.356 & $10,613.29$ & $1.53 \mathrm{E}+16$ & 8076.916 & $248,463.6$ & $13,071.94$ \\
Observations & 38 & 38 & 38 & 38 & 38 & 38 \\
\hline
\end{tabular}

Source: Author's calculation from the E-view 


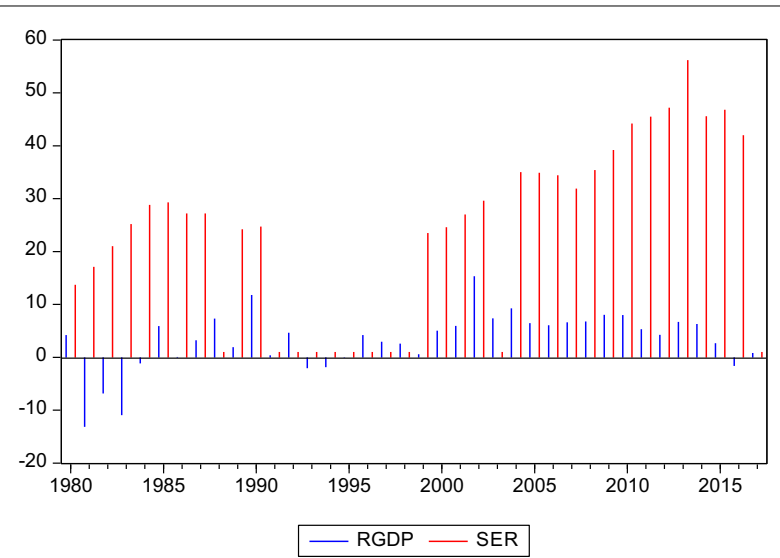

Fig. 1 The trends between real gross domestic products and government expenditure

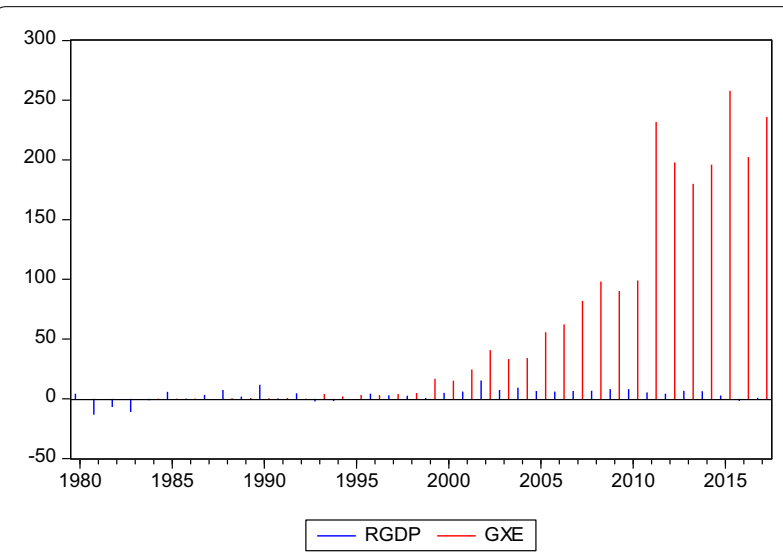

Fig. 2 The trends between real gross domestic products, student enrolment and government expenditure

while GXE is mesokurtic, and RGDP and GCF are platykurtic. Jarque-Bera is used to test for normality of the series, whether they are normally distributed or not. And it is detected that $5 \%$ level of insignificant indicates that the residuals are normally distributed.

\section{The trend analysis}

The trends between real gross domestic products and student enrolment are shown in Figs. 1, 2, 3.

Unit root and statistical attributes in Table 2 explain all the series in the model. This is to show the estimates of the first difference among the series in the model. Ho: indicates the presence of unit root in the series, while Hi: implies the absence unit root in the series. The null hypothesis, according to statistical rule, states that there is a unit root in each of the series that is each variable is non-stationary. Intuitively, the null hypothesis cannot

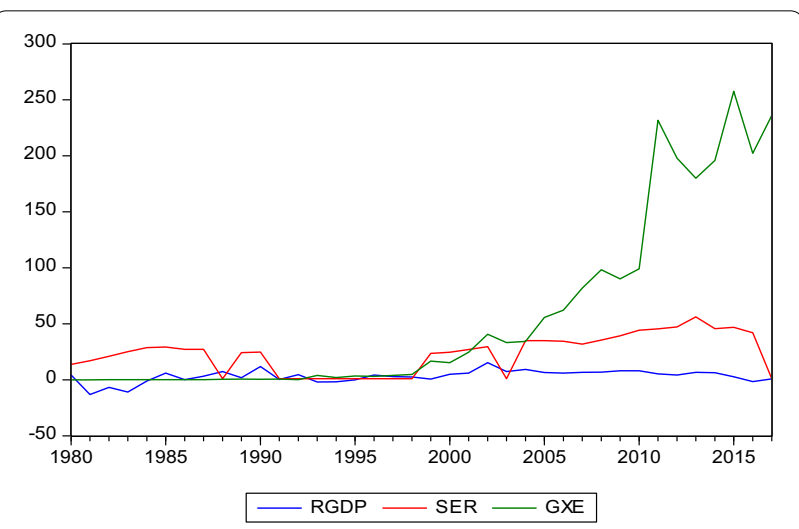

Fig. 3 It is observed that human capital indicators trends on real gross domestic products over the years were quite fluctuating. For example, school enrolment started on a very high note from 1980 to 1991. It continued to experience sharp drop till 1998 before it later rose quickly in 1999 till 2004 and move speedily upward till 2015. It dropped acutely in the late 2015 till 2017 with steady drop in real growth, while government expenditure on education, despite starting on a stable note, it continued to rise sharply from 1998 till 2010, and drop a bit between 2011 and 2013 before it rose again in 2014 with slight drop in 2015 and later rise in 2016 till 2017 with continuous steady drop in real gross domestic products. Source: Author's calculation from the E-view

Table 2 Unit root test

\begin{tabular}{llll}
\hline Unit root test & ADF T-statistics & $\begin{array}{l}\text { Order of } \\
\text { integration }\end{array}$ & Prob. value \\
\hline RGDP & -11.3341 & $\mid(1)$ & 0.0000 \\
SER & -6.79052 & $\mid(1)$ & 0.0000 \\
TLF & -6.1343 & $\mid(1)$ & 0.0001 \\
LPR & -5.64936 & $\mid(1)$ & 0.0002 \\
GXE & -6.29631 & $\mid(1)$ & 0.0000 \\
GCF & -5.49102 & $\mid(1)$ & 0.0001 \\
\hline
\end{tabular}

Source: Author's calculation from the E-view

be rejected if the ADF statistic is greater than critical value at various significance levels. Meaning that, whenever the absolute value of ADF is higher than the critical, the rule of thumb states that the null hypothesis of no instability in the series should be accepted. Augmented Dickey-Fuller reveals RGDP, TLF, LPR, GXE and GCF. Are integrated of order one, i.e. I (1). This kind of harmonised outcomes rarely occurs. Based on the unified ADF test results, it means the condition for vector error correction mechanism (VECM) and Johansen cointegration tests are met.

\section{Summary of vector error correction mechanism test}

Drawings from the unit root test outcome necessitated the adoption of vector error correction mechanism 
(VECM) and Johansen cointegration tests in this study [8]. The unified outcome of the unit root at the first difference predated these techniques. In the view of the above, it is pertinent to elucidate the VECM models in the study.

Hence, the short-run model is expressed thus:

$$
\begin{aligned}
\triangle R G D P= & -0.52034 E C T_{t-1}-0.13398 R G D P_{t-1} \\
& +0.185486 R G D P_{t-2}+0.044683 S E R_{t-1} \\
& +0.016297 S E R_{t-2}-6.82 E-07 T L F_{t-1}-8.03 E \\
& -07 T L F_{t-2}+0.280663 L P R_{t-1}+0.678804 L P R_{t-2} \\
& -0.03962 G X E_{t-1}+0.001942 G X E_{t-2}-0.04902 G C F_{t-1} \\
& +0.03445 G C F_{t}-20.03445+2.168802 .
\end{aligned}
$$

While $\mathrm{ECT}_{t-1}$ is used to explain the cointegration equation and long-run model.

$$
\begin{aligned}
E C T_{t-1}= & {\left[1.000 R G D P_{t-1}-0.3047 S E R_{t-1}+4.67 E-07 T L F_{t-1}\right.} \\
& -0.60631 L P R_{t-1}-0.04219 G X E_{t-1} \\
& \left.+0.095628 G C F_{t-1}+3.174478\right]
\end{aligned}
$$

It is significant to conclude that there are both shortrun and long-run relationships between human capital development and economic growth in Nigeria. Firstly, the short-run VECM relationship shall be discussed, before analysis of the long-run co-integrating relationships. Notably, $-0.5203 \mathrm{ECT}_{t-1}$ explains that the previous year deviation from long-run equilibrium is being corrected in the current period at an adjusted speed of 52.034 per cent, while $0.044683 \mathrm{SER}_{t-1}$ means a per cent change in school enrolment is associated with 0.044 increase in real gross domestic product ceteris paribus. $-6.82 \mathrm{E}-07 \mathrm{TLF}_{t-1}$ implies a per cent change in total labour force is associated with 6.82-07 decrease real gross domestic product ceteris paribus. And $0.280663 \mathrm{LPR}_{t-1}$ indicates a per cent change in labour participation rate is associated with 0.287 increase real gross domestic product ceteris paribus. Meanwhile, $-0.03962 \mathrm{GXE}_{\mathrm{t}-1}$ denotes a per cent

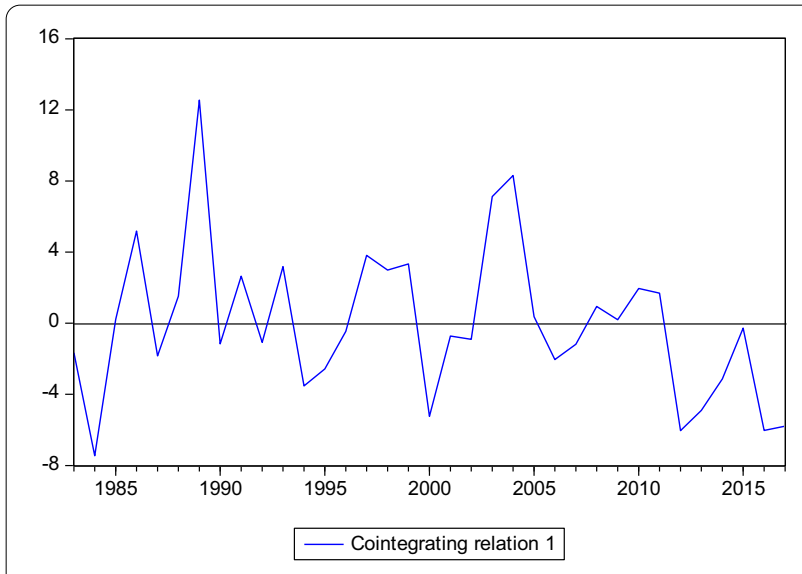

Fig. 4 Johansen cointegrating graph and results
Table 3 Cointegrating results

\begin{tabular}{llll}
\hline & Coefficient & Standard error & Probability value \\
\hline GDP & & & \\
TLF & $4.67 E-07$ & $-1.90 E-07$ & $0.0100^{* * *}$ \\
GXE & -0.04219 & -0.02373 & 0.1200 \\
LPR & -0.606309 & -0.18574 & $0.0000^{* * *}$ \\
GCF & 0.095628 & -0.05329 & 0.1100 \\
SER & -0.304702 & -0.05788 & $0.0000^{* * *}$ \\
\hline
\end{tabular}

Source: Author's calculations from the E-view

$\left(^{* * *}\right)$ denotes $\left.1 \%,{ }^{* *}\right)$ explains $5 \%$ and $(*)$ implies $10 \%$ statistical significant levels, respectively

change in government expenditure on education is associated with 0.0396 decrease in real gross domestic product ceteris paribus (Fig. 4 and Table 3 ).

The cointegrating graph result discloses the stability of series in the model. It is observed that the series values oscillate around the zero mean throughout the period under review. This further confirms the longrun stability of the model. Also, the results from trace statistic and max-eigen statistic reveal that the null hypothesis of no cointegration can be rejected. Meaning that there is at least one co-integrating series in the model specified. Evidently, the trace statistics value 111.4263 is greater than the critical value of 95.75366 , with the probability value of 0.0027 . And the maximum eigen value statistic of 47.77697 is higher than the critical value of 40.07757, which further establishes that cointegration subsists among the series employed in the analysis.

Furthermore, one cointegrating equation(s) and loglikelihood value of -1019.532 guide us through the Johansen normalised cointegrating coefficients, which is specified below thus:

$$
\begin{aligned}
\triangle R G D P= & -0.304702 S E R 4.67 E-07 T L F-0.606309 L P R \\
& -0.04219 G X E 0.095628 G C F(-0.05788) \\
& (-1.90 E-07)(-0.18574)(-0.02373)(-0.05329)
\end{aligned}
$$

where the standard errors are in parentheses. According to the rule of thumb, the normalised cointegrating model is reversely interpreted, that is the signs of the coefficients are reversed in the long run. It is worthy to note that in the study, school enrolment has positive impact of real economic growth, while total labour force poses negative impact on real economic growth on the average, whereas both labour force and government expenditure on education have positive impact on real economic growth on the average and lastly the gross capital formation has negative impact on the economic growth level, ceteris paribus. Conclusively, the estimated coefficients of human capital have a significant impact on 
Table 4 Diagnostic test result

\begin{tabular}{ll}
\hline Test & LM-Stat (Prob) \\
\hline VEC residual serial correlation LM tests & Lag: (1) $36.66536(0.4378)$ \\
VEC residual heteroskedasticity tests & Lag: (2) $31.2886(0.6921)$ \\
\hline
\end{tabular}

Source: Author's calculation from the E-view

the real economic growth in Nigeria at 1\% level that is, the estimation of $\mathrm{t}$-statistics guides us that the series are significant at one per cent level. In a nut shell, the null hypothesis of no cointegration in the model is entirely rejected.

After estimating the short- and long-run analysis, it is vital to establish whether our previous results are valid as well as in accordance with the ordinary least squares assumptions, that is, how efficiency and consistency are the results so far estimated within the model. From Table 4, VEC residual serial correlation LM test suggests that there is no serial autocorrelation in the model since the probability value is greater than $5 \%$ significant level across the lag length periods. Hence, the hypothesis of no autocorrelation for residuals cannot be rejected. VEC residual heteroskedasticity tests suggest that the series are homoskedastic in nature. Therefore, the hypothesis of no heteroskedasticity cannot be rejected in the study. Based on the above estimation, we can therefore conclude that the series specified in the model during cause of the study so far are consistent, which make our overall results to be efficient and valid.

\section{Conclusion}

Having empirically sought for the impact of human capital development on the Nigerian economic growth between 1981 and 2017, it is largely concluded based on our discoveries and discussion of findings that longrun and short-run relationship subsists between human capital and economic growth in Nigeria. It is therefore concluded that human capital has significant effects on the Nigerian economic growth during the years under review. Moreover, it is concluded that Johansen test confirmed that the variables are co integrated. That is, there is long-run nexus between human capital indicators and economic growth indicator in Nigeria. The human capital has a significant effect on the Nigerian economic growth. Human capital indicators like students' enrolment rate, labour participation rate and total labour force are important determinants of the Nigerian economic growth. Interestingly, inferences from this research corroborate with the views of Adelakun, [3], Adeyemi and Ogunsola [2], whereas Ekesiobi et al. [7], Amassoma and Nwosa [4] and Obi and Obi [15] have contrary views on the link between human capital development and economic growth in Nigeria.

In view of the background to the study, it is pertinent to come up with the following recommendations thus: Firstly, government should establish special agencies with the obligation of improving the skills and capabilities of students (labours) across all educational levels of the federation so as to sustain long-run economic growth. Secondly, efforts should be geared towards improving education and health sector in terms of increased governmental budgetary allocation for continuous growth sustainability. To this end, findings from this study would serve as future policy guide to both the relevant government agencies like Central Bank of Nigeria, on the need to look inward by making its fiscal policy design to be labour oriented through tax incentives that can motivate productivity rate. Also, findings from this research would help the Bank of Industry and Ministry of Labour among others to come up with continuous training and re-training of labour towards improve labour participation rate. International agencies like World Bank and World Trade Organisation can benefit from the findings and recommendations from this study. Results and suggestions can be used as guide in the future trades and transactions. However, future researchers are advised to focus on the impact of human capital on manufacturing growth in Nigeria, as this would narrow down the disconnections that persist on the link between human capital and economic growth.

\section{Abbreviations}

GDP: Gross domestic product growth rate; GCF: Gross capital formation; LPR: Labour participation rate; SER: Student enrolment; TLF: Total labour force; GXE: Government expenditure.

\section{Acknowledgements}

I hereby appreciate my universities-Federal University Oye-Ekiti, Ekiti State, Nigeria, and University of Kwuazulu-Natal, Durban, South Africa, for given me the opportunity to carry out part of my PhD thesis work for progression.

\section{Authors' contributions}

I, SAK, did everything in the research article from introduction to the conclusion and recommendations. The author has read and approved the final document.

\section{Funding}

Not applicable.

Availability of data and materials

This is available on request.

\section{Declarations}

Consent for publication

I hereby agreed that my submitted manuscript "Human Capital and Economic Growth in Nigeria" be published by your firm. 


\section{Competing interests}

The author declares that he has no competing interests.

\section{Author details}

${ }^{1}$ Department of Economics, Federal University Oye-Ekiti, Oye, Ekiti State, Nigeria. ${ }^{2}$ University of Kwuazulu-Natal, Durban, South Africa.

Received: 4 June 2021 Accepted: 14 August 2021

Published: 16 November 2021

\section{References}

1. Adamu PA (2003) The impact of human capital formation on economic development in Nigeria: an error correction approach. In: Selected Papers for 2002 Annual Conference, Human Resource Development in Africa. Nigerian Economic Society, Ibadan. pp 53-78

2. Adeyemi PA, Ogunsola AJ (2016) The impact of human capital development on economic growth in Nigeria: ARDL approach. IOSR J Hum Soc Sci 21(3):1-7

3. Adelakun OJ (2011) Human capital development and economic growth in Nigeria. Eur J Bus Manag 3(9):29-37

4. Amassoma D, Nwosa PI (2011) Investment in human capital and economic growth in Nigeria: a causality approach. Can Soc Sci 7(4):114-120

5. Borojo DG, Jiang Y (2016) The impact of Africa-China trade openness on technology transfer and economic growth for Africa: a dynamic panel data approach. Ann Econ Finance 17(2):403-431

6. Eigbiremolen GO, Anaduaka US (2014) Human capital development and economic growth: the Nigeria experience. Int J Acad Res Bus Soc Sci 4(4):25-35. https://doi.org/10.6007/IJARBSS/v4-i4/749

7. Ekesiobi CS, Dimnwobi SK, Ifebi OE, Ibekiol BN (2015) Public sector education investment and manufacturing output in Nigeria: empirics and policy options. Public Policy Admin Res 6(7):95-106

8. Engle RF, Granger CWJ (1987) Cointegration and error correction representation, estimation and testing. Econometrica 55(2):252-276

9. Harbinson FH (1973) Human resources as wealth of nations. Oxford University Press, London

10. Jhingan ML (2005) The economics of development planning, 38th edn. Vrinda Publications (P) Ltd, Delhi
11. Kairo Cl, Mang NJ, Okeke A, Aondo DC (2017) Government expenditure and human capital development in Nigeria: an auto-regressive distributed lagged model approach (ARDL). Int J Adv Stud Econ Public Sec Manage 5(1):143-158

12. Lubna I, Awan AG, Tayyab M (2018) Impact of health and education on the level of productivity: evidence from Pakistan. Global J Manag Soc Sci Hum 4(4):933-947

13. Makuta I, O'Hare B (2015) Quality of governance, public spending on health and health status in Sub Saharan Africa: a panel data regression analysis. BMC Public Health 15(932):1-11. https://doi.org/10.1186/ s12889-015-2287-z

14. Mankiw NG, Romer D, Weil D (1992) A contribution to the empirics of economic growth. Quart J Econ 107:407-438

15. Obi ZC, Obi CO (2014) Impact of government expenditure on education: the Nigerian experience. Int J Bus Finance Manag Res 2(2104):42-48

16. Oladeji AO (2015) Impact of human capital development on economic growth in Nigeria. Int J Recent Res Comm Econ Manag 2(2):151-164

17. Olalekan O (2014) Human capital and economic growth in Nigeria. Int Innov Sci Res 11(2):291-294

18. Oluwatobi S, Olurinola IO (2011) Government expenditure on human capital development: implications for economic growth in Nigeria. J Sustain Dev 4(3):72-80. https://doi.org/10.5539/jsd.v4n3p72

19. OECD (1996) Organisation for economic cooperation and development. The knowledge-based economy. OECD, Paris

20. Solow RM (1956) A contribution to the theory of economic growth. Q J Econ 70:65-94

21. Todaro MP, Smith SC (2003) Economic development. Addison Wesley, Boston

22. UNISCO (2011) Financing education in Sub-Saharan Africa: meeting the challenges of expansion, equity and quality; UNESCO Institute for Statistics. http://www.uis.unesco.org

\section{Publisher's Note}

Springer Nature remains neutral with regard to jurisdictional claims in published maps and institutional affiliations.

\section{Submit your manuscript to a SpringerOpen ${ }^{\circ}$ journal and benefit from:}

- Convenient online submission

- Rigorous peer review

- Open access: articles freely available online

- High visibility within the field

- Retaining the copyright to your article

Submit your next manuscript at springeropen.com 